\title{
Successful Treatment of Malignant Priapism by Radiotherapy: Report of a Case, Review of the Literature, and Treatment Recommendations
}

\author{
Daniel T. Xing ${ }^{1}$, Helene Yilmaz ${ }^{2}$, Supan Hettige ${ }^{3}$, Rajendra Hegde ${ }^{3,4}$, Rohan Nair ${ }^{3,4}$ \\ 1. Oliver Newton-John Cancer Wellness and Research Centre, Austin Health, Melbourne, AUS 2. Pathology, TissuPath, \\ Melbourne, AUS 3. Gippsland Radiation Oncology, Latrobe Regional Hospital, Traralgon, AUS 4. Radiation Oncology, \\ William Buckland Radiotherapy Centre, The Alfred Health, Melbourne, AUS
}

Corresponding author: Rohan Nair, rnair@lrh.com.au

\begin{abstract}
Malignant priapism is a condition of painful induration and erection of the penis secondary to metastatic infiltration by a neoplasm. This condition is associated with a poor prognosis. We report on a case of an 87year-old man who presented with a painful, partially erected penis subsequent to a diagnosis of metastatic Gleason 4+5 prostate cancer. Magnetic resonance imaging (MRI) showed diffuse bilateral infiltration of his corpora cavernosa. The core biopsy of the penile nodule revealed it to be a poorly differentiated carcinoma consistent with prostatic origin. The patient's symptoms were completely resolved after treatment with high-dose palliative conformal radiotherapy (40Gy in 16 fractions). We systemically reviewed clinical reports of palliative radiotherapy for malignant priapism with the aim to gain more information on the management of this rare condition.
\end{abstract}

Categories: Radiation Oncology

Keywords: priapism, prostate cancer, radiotherapy, palliative radiation therapy, volumetric modulated arc therapy

\section{Introduction}

Penile metastasis is a rare phenomenon, first described in 1870 by Eberth. Since then, about 460 cases have been reported in the literature [1-3]. The most common causes of this condition are genitourinary (especially prostate and bladder primaries) and recto-sigmoid primary malignancies [4]. About 20-30\% of patients with penile metastasis reported in the literature presented with priapism [5-6]. Malignant priapism is a condition of painful induration and erection of the penis secondary to metastatic infiltration by a neoplasm. Here, we describe a case of malignant priapism secondary to prostate adenocarcinoma. The patient achieved longlasting symptomatic relief after receiving high-dose palliative radiotherapy to the penis.

Review began 08/02/2021 Review ended 08/13/2021 Published 08/18/2021

\section{(c) Copyright 2021}

Xing et al. This is an open access article distributed under the terms of the Creative Commons Attribution License CC-BY 4.0., which permits unrestricted use, distribution, and reproduction in any medium, provided the original author and source are credited.

\section{Case Presentation}

An 87-year-old man with metastatic prostate adenocarcinoma presented with painful and persistent partially erected penis He was previously diagnosed with prostate cancer in 1998 with a prostate-specific antigen (PSA) of $70 \mu \mathrm{g} / \mathrm{L}$ and T3 disease. It was unclear if he had metastatic disease at the time of diagnosis, The patient had been continuously treated with hormonal therapy since his initial diagnosis of prostate cancer. Upon presentation, the patient had low volume bony disease on the seventh cervical spine, first thoracic spine, left femur, and right tibia on a whole-body bone scan. We instituted treatment with leuprorelin and bicalutamide. The patient's PSA was reduced to $0.75 \mu \mathrm{g} / \mathrm{L}$.

Figure 1 shows the magnetic resonance imaging (MRI) scan. 


\section{Cureus}

A

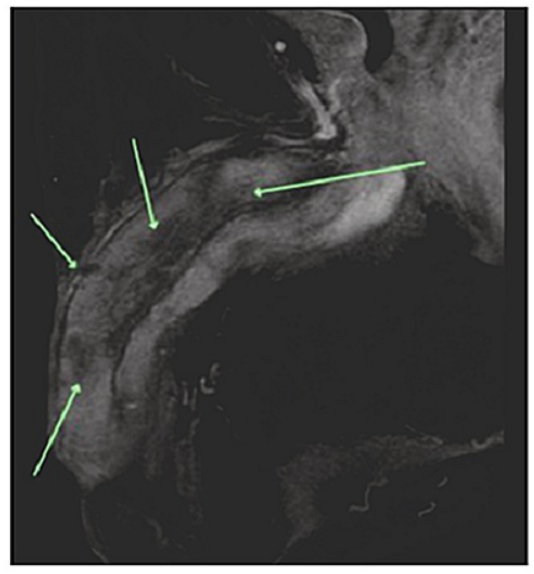

B

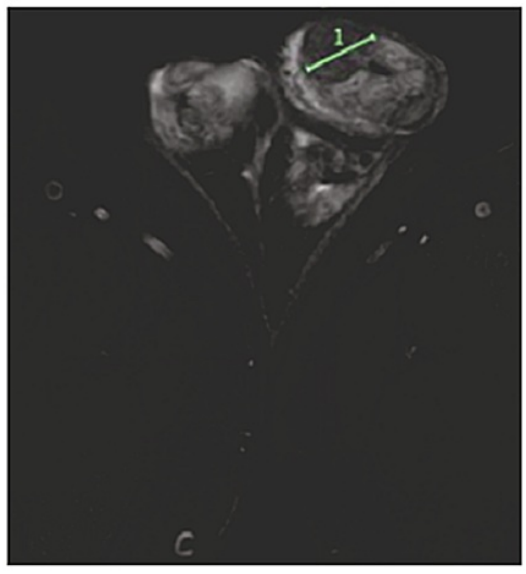

\section{FIGURE 1: Penile MRI scan of the patient}

A) Sagittal view of T1 fat suppression sequence with contrast. Arrow: reduced contrast uptake. B) Axial view of T2 fat suppression sequence, 1 Length: $1.92 \mathrm{~cm}$

MRI showed the heterogeneous signal intensity of the bilateral corpora cavernosa with enhancement. There were poorly defined areas with reduced contrast uptake. There also appeared to be nodules on the right aspect of the glans of the penis and corpus cavernosum involving the tunica albuginea.

Histological examination of the core biopsy of the penile mass revealed a poorly differentiated carcinoma comprising epithelioid tumor cells with nested and sheet-like architecture, nuclear pleomorphism, prominent nucleoli, and scattered mitotic figures (Figure 2, panel A).

A

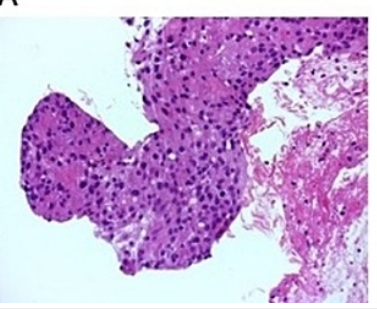

B

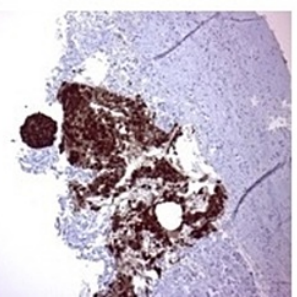

C

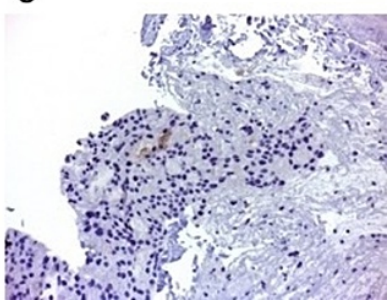

\section{FIGURE 2: Histological examination of the core biopsy of the penile} mass from the patient

A) Medium power view showing poorly differentiated carcinoma on hematoxylin and eosin-stained section. B) Poorly differentiated carcinoma highlighted with CK20 stain. C) Poorly differentiated carcinoma with focal staining for prostate-specific membrane antigen (PSMA).

Immunohistochemistry showed tumor cells with positive staining for CK7 and CK20 (Figure 2, panel B), as well as very focal positive staining for PSMA (Figure 2, panel C). GATA3, CK5/6, p63, and PSA stains returned negative. Whilst the presence of staining for CK7 and CK20 is unusual for prostatic adenocarcinoma, a previous prostatic biopsy had shown a similar immunohistochemical staining profile (i.e. with positive staining for CK7, CK20, PSMA, PSAP, and focal staining for PSA); hence, the penile mass biopsy was favored to be metastatic prostatic adenocarcinoma.

The patient had previously received high-dose palliative radiotherapy to the prostate primary (60Gy in 30 fractions). The patient remained to have good performance status. Therefore, we chose to use volumetric modulated arc therapy (VMAT) to deliver moderately hypofractionated high-dose radiotherapy to the penis with the aim to reduce damage to normal pelvic tissue. The patient was treated in a supine position with a 1 $\mathrm{cm}$ bolus administered to the penis. The air gap was filled with wet gauze. We initially planned to deliver doses up to 50Gy in 20 fractions. The radiation dosimetry is shown in Figure 3. 


\section{Cureus}

A

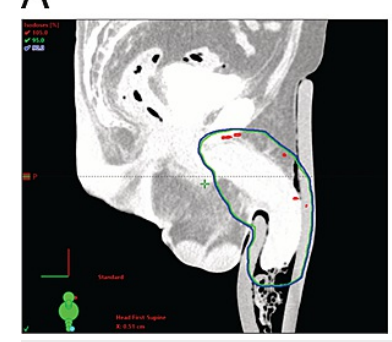

$\mathrm{B}$

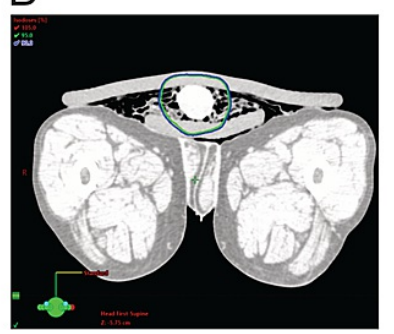

C

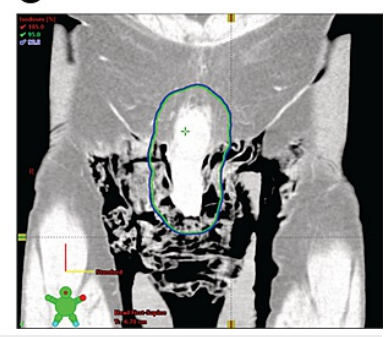

FIGURE 3: Radiotherapy dosimetry plan for the patient

A) Sagittal view. B) Transverse view. C) Coronal view.

Blue: $90 \%$ isodose line; Green: $95 \%$ isodose line; Red: $105 \%$ isodose line

The dose-volume histogram (DVH) of the current plan is shown in Figure 4, panel A.

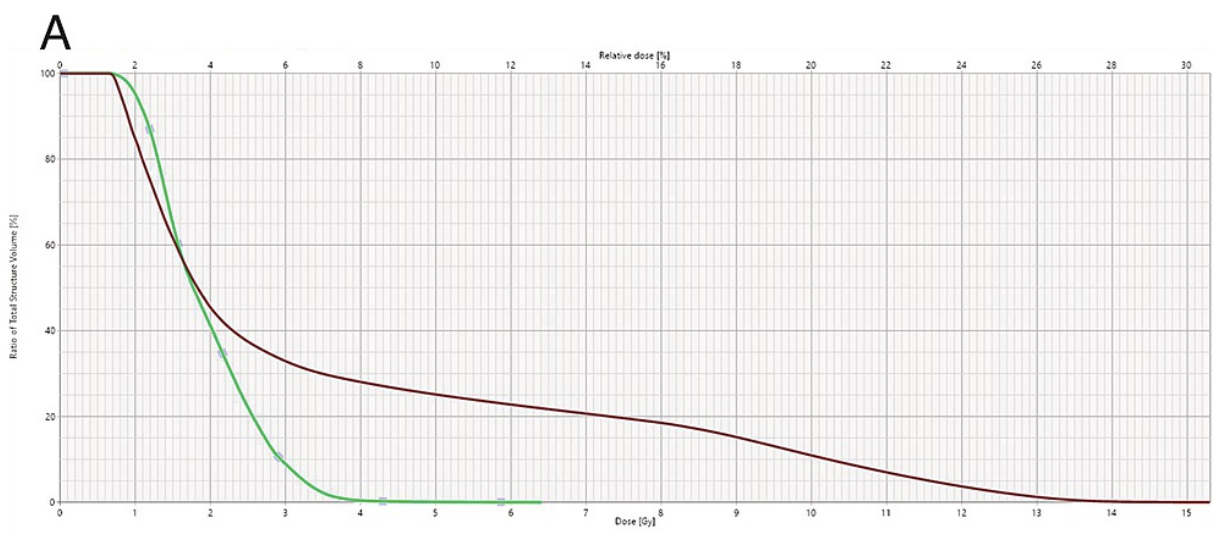

$\mathrm{B}$

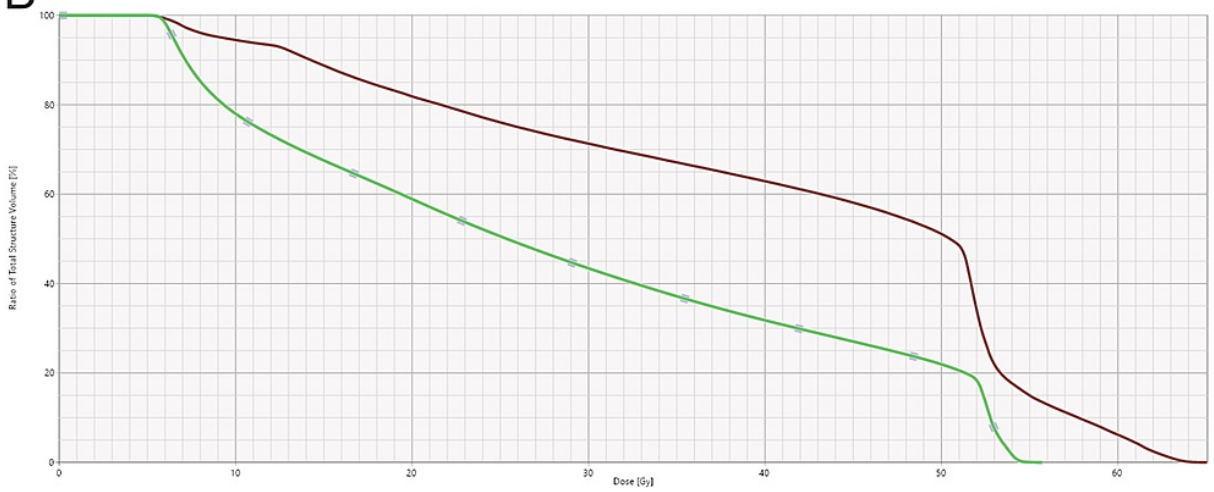

FIGURE 4: Dose-volume histogram (DVH) of bladder and rectum

A) The current course of radiotherapy. B) Combined DVH of the current plan with previous pelvic radiotherapy.

The bladder and rectum received a very low dose wash. The combined DVH of the bladder and rectum from two courses of pelvic radiotherapy is shown in Figure 4, panel B. Both the bladder and rectum met the dose constraints as per our departmental policy. Daily cone-beam CTs were used for treatment setup verification. However, the patient developed a grade 3 skin reaction of the penis and thus treatment was ceased at 40Gy.

The patient achieved complete symptomatic relief and acute skin toxicity was resolved at two months postradiotherapy. The patient was switched to androgen depression therapy with abiraterone. At nine months post-radiotherapy, his PSA remains at a low level $(0.13 \mu \mathrm{g} / \mathrm{L})$. He remains symptom-free and maintains excellent urinary function. He further reports a good quality of life at nine months post-radiotherapy. 


\section{Cureus}

\section{Discussion}

We carried out a structured literature search regarding malignant priapism and its treatment. The search was limited to English language literature available on the MEDLINE database and to case reports occurring between January 1940 and December 2018. The search terms included priapism, penile, metastasis, radiotherapy, and radiation.

We identified 42 cases reports of malignant priapism secondary to prostate adenocarcinoma, urothelial carcinoma, renal cell carcinoma, rectal adenocarcinoma, caecal carcinoma, oesophageal carcinoma, nonsmall cell lung cancer, chondrosarcoma, chordoma, melanoma, and lymphoma (Table 1).

\begin{tabular}{|c|c|c|c|}
\hline Primary Histopathology & No. of cases & No. of cases treated with $\mathbf{R T}^{\mathrm{a}}$ & No. of cases with RT details \\
\hline Prostate Adenocarcinoma & 13 & 5 & 2 \\
\hline Bladder urothelial Ca. & 9 & 2 & 2 \\
\hline Renal cell Ca. & 5 & 2 & 1 \\
\hline Ureter urothelial Ca. & 1 & 1 & 0 \\
\hline Rectal adenocarcinoma & 3 & 2 & 2 \\
\hline Caecal Ca. & 2 & 0 & 0 \\
\hline Oesophageal Ca. & 1 & 1 & 1 \\
\hline NSCLC & 4 & 2 & 1 \\
\hline Chondrosarcoma & 1 & 1 & 1 \\
\hline Chordoma & 1 & 1 & 1 \\
\hline Melanoma & 1 & 1 & 1 \\
\hline Lymphoma & 1 & 0 & 0 \\
\hline Total & 42 & 16 & 12 \\
\hline
\end{tabular}

\section{TABLE 1: Cases of malignant priapism treated with radiotherapy}

aRT: radiotherapy for malignant priapism. Ca: carcinoma. NSCLC: non-small cell lung cancer.

The details of the reviewed case reports are described in Table 2.

\begin{tabular}{|c|c|c|c|c|}
\hline $\begin{array}{l}\text { Primary / } \\
\text { Histopathology }\end{array}$ & Citation & $\begin{array}{l}\text { Radiotherapy } \\
\text { (Y/N) }\end{array}$ & $\begin{array}{l}\text { Description of radiotherapy } \\
\text { technique/dose }(\mathrm{Y} / \mathrm{N})\end{array}$ & Other treatment \\
\hline \multicolumn{5}{|l|}{ Genitourinary tract } \\
\hline \multicolumn{5}{|l|}{ Prostate } \\
\hline Adenocarcinoma & Mc 1954 [7] & $N / A^{a}$ & N/A & N/A \\
\hline Adenocarcinoma & Witters, Cornelissen et al. 1985 [8] & N/A & N/A & Palliative \\
\hline Adenocarcinoma & Osther and Lontoft 1991 [9] & $\mathrm{N}$ & $\mathrm{N}$ & Hormonal \\
\hline Adenocarcinoma & Buchholz, Moch et al. 1994 [10] & $\mathrm{Y}$ & $\mathrm{N}$ & Hormonal \\
\hline Adenocarcinoma & $\begin{array}{l}\text { Schroeder-Printzen, Vosshenrich } \\
\text { et al. } 1994 \text { [11] }\end{array}$ & $\mathbf{N}$ & $\mathrm{N}$ & Palliative, hormonal \\
\hline Adenocarcinoma & Chan, Begin et al. 1998 [6] & $\mathrm{N}$ & $\mathrm{N}$ & Hormonal \\
\hline Adenocarcinoma & Cante, Franco et al. 2014 [12] & $\mathrm{Y}$ & $\mathrm{Y}$ & Hormonal \\
\hline Adenocarcinoma & Kitley, Mosier et al. 2010 [13] & $\mathbf{Y}$ & $\mathrm{Y}$ & Hormonal \\
\hline
\end{tabular}




\section{Cureus}

Adenocarcinoma [14]

Adenocarcinoma

Mixed urothelial $\mathrm{Ca}$ and

adenocarcinoma

Adenocarcinoma

Adenocarcinoma

Urinary bladder

Urothelial Ca.

Urothelial Ca.

Urothelial Ca.

Urothelial Ca.

Urothelial Ca.

Urothelial Ca.

Urothelial Ca.

Urothelial Ca.

Urothelial Ca.

Kidney

Renal cell $\mathrm{Ca}$.

Renal cell Ca.

Renal cell Ca.

Renal cell Ca.

Renal pelvic carcinoma

Ureter

Urothelial Ca.

Gastrointestinal tract

Rectal adenocarcinoma

Rectal adenocarcinoma

Rectal adenocarcinoma

Caecal carcinoma

Caecal carcinoma

Oesophageal carcinoma

Other

Lung SCC

Lung SCC

Lung SCC

Lung adenosquamous

carcinoma da Silva Gaspar, Nunes et al. 2015

N

Hormona

Penectomy,

hormonal

Savion, Livne et al. 1987 [16] $\quad$ Y $\quad$ N

Hormonal

Lin, Kim et al. 2011 [2]

$\mathrm{N}$

N

Palliative

Barrett-Campbell, Petkovska et al. 2018 [17]

Chemotherapy,

hormonal

Chemotherapy

Matthewman, Oliver et al. 1987 [18] N

N

Palliative

Palliative

Chan, Begin et al. 1998 [6]

N

Sonmez, Coskun et al. 2009 [20] Y

Y

No

Spinapolice, Fuccio et al. 2014 [21] Y Y

Ellanti, Connolly et al. 2011 [22] N

N

Al-Mufarrej, Kamel et al. 2006 [23] N N

Zhu, Yao et al. 2012 [24]

N

N

Ahmed, Elsamra et al. 2012 [25] N

Palliative

Penectomy,

chemotherapy

Penectomy

Penectomy

Immunotherapy

Surgery

Immunotherapy

Puppo, Perachino et al. 1992 [27] N N

No

Palliative

Zhu, Xue et al. 2014 [29]

N N

Surgery

Valadez, Wheeler et al. 1987 [31]

N

No

Nunes, Matias et al. 2015 [32] $\quad$ Y $\quad$ Y

Chemotherapy

Park, Lee et al. 2009 [33] $\quad$ Y $\quad$ Y

Chemotherapy

Persec, Persec et al. 2014 [34] N N

Palliative

Kapoor, Bera et al. 2012 [35] N N N

Chemotherapy

Sasikumar, Harisankar et al. 2013

[36]

N/A

N/A

N/A

Song, Wang et al. 2019 [37]

Y

Chemotherapy

No

Palliative

Radiotherapy to bony metastasis

Fujimoto, Hiraki et al. 2001 [40] Y $\quad$ Y

Penectomy 


\section{Cureus}

$\begin{array}{lllll}\begin{array}{l}\text { Chondrosarcoma of the } \\ \text { jaw }\end{array} & \begin{array}{l}\text { Cardoso Guimarães, Rodrigues De } \\ \text { Souza et al. 2003 [42] }\end{array} & \text { Y } & \text { Chemotherapy } \\ \begin{array}{l}\text { Sacrococcygeal } \\ \text { chordoma }\end{array} & \text { Mondaini, Mondaini et al. 2005 [43] } & \text { Y } & \text { Y } & \text { Palliative } \\ \text { Melanoma } & \text { Sagar and Retsas 1992 [44] } & \text { Y } & \text { Y } \\ \text { Lymphoma } & \text { Gong, Zhang et al. 2014 [45] } & \text { N } & \text { N } & \text { Palliative }\end{array}$

\section{TABLE 2: Cases of malignant priapism reviewed}

NA: information unavailable. Ca: carcinoma. SCC: squamous cell carcinoma.

In 16 cases, palliative radiotherapy was used to treat malignant priapism. The radiotherapy dose fractionation was reported only in 12 cases (Table 3).

\begin{tabular}{|c|c|c|c|c|}
\hline $\begin{array}{l}\text { Primary site \& } \\
\text { histopathology }\end{array}$ & Investigator & Radiotherapy technique & Dose and fractionation & Outcome \\
\hline $\begin{array}{l}\text { Prostate } \\
\text { adenocarcinoma }\end{array}$ & Kitley C [13] & NR & $\begin{array}{l}\text { 40Gy to prostate, base of } \\
\text { bladder, and penis }\end{array}$ & Slow resolution of priapism \\
\hline $\begin{array}{l}\text { Prostate mucinous } \\
\text { adenocarcinoma }\end{array}$ & Cante D [12] & 3D-CRT & 35Gy in 14 fractions & $\begin{array}{l}\text { Complete pain relief and objective } \\
\text { response }\end{array}$ \\
\hline $\begin{array}{l}\text { Bladder urothelial } \\
\text { carcinoma }\end{array}$ & $\begin{array}{l}\text { Sonmez NC } \\
{[20]}\end{array}$ & NR & $56 \mathrm{~Gy}$ & Partial resolution of priapism \\
\hline $\begin{array}{l}\text { Bladder urothelial } \\
\text { carcinoma }\end{array}$ & $\begin{array}{l}\text { Spinapolice } \\
\text { E [21] }\end{array}$ & 3D-CRT & 30Gy in 10 fractions & $\begin{array}{l}\text { Complete pain relief and } \\
\text { resolution of priapism }\end{array}$ \\
\hline Renal cell carcinoma & $\begin{array}{l}\text { Nezu FM } \\
{[28]}\end{array}$ & NR & 25 Gy in 10 fractions & $\begin{array}{l}\text { Partial pain relief and decrease in } \\
\text { size of erection }\end{array}$ \\
\hline $\begin{array}{l}\text { Rectal } \\
\text { adenocarcinoma }\end{array}$ & $\begin{array}{l}\text { Nunes, B } \\
\text { [32] }\end{array}$ & $\begin{array}{l}\text { 3D-CRT (one direct } \\
\text { anterior electron field) }\end{array}$ & 30 Gy in 10 fractions & $\begin{array}{l}\text { No acute toxicity; complete } \\
\text { response }\end{array}$ \\
\hline $\begin{array}{l}\text { Rectal } \\
\text { adenocarcinoma }\end{array}$ & Park JC [33] & NR & 33.8Gy in 13 fractions & NR \\
\hline Oesophageal SCC & Song L [37] & 3D-CRT & $60 \mathrm{~Gy}$ in 30 fractions & NR \\
\hline Lung SCC & $\begin{array}{l}\text { Fujimoto N } \\
{[40]}\end{array}$ & JR & 60 Gy in 30 fractions & $\begin{array}{l}\text { Partial regression of priapism and } \\
\text { complete pain relief }\end{array}$ \\
\hline Melanoma & $\begin{array}{l}\text { Sagar SM } \\
{[44]}\end{array}$ & nterior field & $\begin{array}{l}18 \mathrm{~Gy} \text { in } 3 \text { fractions, } 1 \\
\text { fraction per week }\end{array}$ & $\begin{array}{l}\text { Pain relief and resolution of penile } \\
\text { induration }\end{array}$ \\
\hline $\begin{array}{l}\text { Chondrosarcoma of } \\
\text { jaw }\end{array}$ & $\begin{array}{l}\text { Guimaraes } \\
\text { GC [42] }\end{array}$ & NR & 25 Gy & $\begin{array}{l}\text { Partial improvement in pain; } \\
\text { decrease in tumor volume }\end{array}$ \\
\hline $\begin{array}{l}\text { Sacrococcygeal } \\
\text { chordoma }\end{array}$ & $\begin{array}{l}\text { Mondaini N } \\
{[43]}\end{array}$ & NR & $20 \mathrm{~Gy}$ in 5 fractions & Partial reduction of penile rigidity \\
\hline
\end{tabular}

TABLE 3: Dose and fractionation of radiotherapy used for the management of malignant priapism NR: not reported. 3D-CRT: 3D conformal radiotherapy. SCC: squamous cell carcinoma.

Malignant priapism is a rare phenomenon with a poor prognosis [5]. It is unlikely a large prospective study for this condition will be conducted, therefore, management of this condition remains challenging. We reported a case of malignant priapism, secondary to prostate adenocarcinoma, which was successfully treated with high-dose palliative radiotherapy (40Gy in 16 fractions using the VMAT technique). We report that the patient achieved long-lasting symptomatic relief, and the acute toxicity from high-dose palliative radiotherapy was tolerable. 
There has been significant improvement in outcomes in patients with metastatic prostate cancer owing to advances in systemic androgen deprivation therapies [46]. However, androgen blockage does not address local symptoms, unlike radiotherapy. There are 13 case reports of malignant priapism secondary to prostate adenocarcinoma, among whom five patients received palliative radiotherapy for priapism symptoms (Table 1). All the patients received concurrent hormonal therapy (Table 2). Unfortunately, only two case reports included brief descriptions of radiation dose fractionation [12-13]. Local symptom control was achieved by administering 35Gy in 14 fractions using the 3D conformal technique [12] to the penis in one case and 40Gy in the other report (fractionation and technique were not described) [13]. Similarly, it has been reported that complete relief pain and priapism can be achieved by locally administering 30Gy in 10 fractions in metastatic bladder urothelial carcinoma [21] and metastatic rectal adenocarcinoma [32] using the 3D conformal technique. On the contrary, priapism symptoms were only partially relieved in earlier case reports $[20,28]$, even with a higher dose (56Gy) [20]. To reconcile the results, it is plausible that the modern conformal radiotherapy technique is better than the field-based technique in terms of ensuring coverage of target and avoiding hotspots or high doses to the organs at risk given the palliative nature of the treatment.

Various doses and fractionations have been reported in the successful treatment of even rarer causes of secondary malignant priapism (Table 3). High-dose radiotherapy (60Gy in 30 fractions) partially relieved priapism symptoms in non-small cell lung cancer, but the acute toxicities were not described in detail [40]. Hypo-fractionated radiotherapy is effective in control priapism secondary to melanoma [44] but not soft tissue neoplasm [42-43]. In sum, these case reports demonstrate that high-dose palliative external beam radiotherapy is an effective palliative option for priapism. However, this option has been relatively underutilized. Only 16 out of 42 malignant priapism cases were reported to be treated with palliative radiotherapy according to our review.

One reason that palliative radiotherapy may be underutilized is that the traditional patient setup is challenging. In the present case, it was very difficult for the patient to tolerate the initial treatment setup, which used a traditional plastic block or wax to hold the penis, due to significant pain. Furthermore, the patient had previously received high-dose radiotherapy to the pelvis. In this case, we used the VMAT technique to overcome these issues. The VMAT setup is simple and comfortable for the patient. Our setup is also reproducible, as we use imaging guidance.

To summarize, the paucity of literature regarding the successful treatment of malignant priapism via radiotherapy means that the optimal radiation dose and fractionation to use is unknown. We recommend high-dose palliative radiotherapy (40-50Gy) for malignant priapism secondary to prostate cancer to achieve durable local control. This dosage was shown to be effective in the current case report and a further two other reports [12-13]. This dose may also be effective for other common causes of malignant priapism (e.g. urothelial carcinoma or rectal carcinoma). The VMAT radiotherapy technique is preferred for two reasons. First, it allows for a simple patient setup and avoids additional stress to the patient. Secondly, malignant priapism is primarily caused by genitourinary or lower gastrointestinal malignancies. Patients with genitourinary or lower gastrointestinal malignancies typically receive high-dose radiotherapy as part of their initial treatment or may require further palliative pelvic radiotherapy. VMAT helps minimize damage to normal pelvic tissues caused by retreatment of radiotherapy.

\section{Conclusions}

Malignant priapism is a rare clinical presentation in patients with metastatic carcinoma. High-dose palliative radiotherapy is an effective treatment for symptomatic relief. Patients need to be monitored closely during treatment to avoid excessive toxicity from radiotherapy.

\section{Additional Information \\ Disclosures}

Human subjects: Consent was obtained or waived by all participants in this study. Conflicts of interest: In compliance with the ICMJE uniform disclosure form, all authors declare the following: Payment/services info: All authors have declared that no financial support was received from any organization for the submitted work. Financial relationships: All authors have declared that they have no financial relationships at present or within the previous three years with any organizations that might have an interest in the submitted work. Other relationships: All authors have declared that there are no other relationships or activities that could appear to have influenced the submitted work.

\section{References}

1. Cherian J, Rajan S, Thwaini A, Elmasry Y, Shah T, Puri R: Secondary penile tumours revisited. Int Semin Surg Oncol. 2006, 3:33. 10.1186/1477-7800-3-33

2. Lin YH, Kim JJ, Stein NB, Khera M: Malignant priapism secondary to metastatic prostate cancer: a case report and review of literature. Rev Urol. 2011, 13:90-4.

3. Abeshouse BS, Abeshouse GA: Metastatic tumors of the penis: a review of the literature and a report of two cases. J Urol. 1961, 86:99-112. 10.1016/s0022-5347(17)65117-6

4. Mearini L, Colella R, Zucchi A, Nunzi E, Porrozzi C, Porena M: A review of penile metastasis . Oncol Rev. 
2012, 6:e10.

5. Cocci A, Hakenberg OW, Cai T, et al.: Prognosis of men with penile metastasis and malignant priapism: a systematic review. Oncotarget. 2018, 9:2923-30. 10.18632/oncotarget.23366

6. Chan PT, Bégin LR, Arnold D, Jacobson SA, Corcos J, Brock GB: Priapism secondary to penile metastasis: a report of two cases and a review of the literature. J Surg Oncol. 1998, 68:51-9. 10.1002/(sici)10969098(199805)68:1<51::aid-jso11>3.0.co;2-u

7. McGA HG: Secondary malignant infiltration of the penis: primary from prostate with priapism . Postgrad Semin Am Urol Assoc North Cent. 1954, 161-3.

8. Witters S, Cornelissen M, Vereecken RL: Malignant priapism. Eur Urol. 1985, 11:431-2. 10.1159/000472557

9. Osther PJ, Løntoft E: Metastasis to the penis. Case reports and review of the literature . Int Urol Nephrol. 1991, 23:161-7. 10.1007/BF02549714

10. Buchholz NP, Moch H, Feichter GE, Schmid HP, Mihatsch MJ: Clinical and pathological features of highly malignant prostatic carcinomas with metastases to the penis. Urol Int. 1994, 53:135-8. 10.1159/000282654

11. Schroeder-Printzen I, Vosshenrich R, Weidner W, Ringert RH: Malignant priapism in a patient with metastatic prostate adenocarcinoma. Urol Int. 1994, 52:52-4. 10.1159/000282571

12. Cante D, Franco P, Sciacero P, et al.: Penile metastasis from prostate cancer: a case report . Tumori. 2014, 100:e14-6.

13. Kitley CA, Mosier AD, Keylock J, Nguyen D: Malignant priapism secondary to adenocarcinoma of the prostate. BMJ Case Rep. 2010, 2010:bcr0720092135. 10.1136/bcr.07.2009.2135

14. da Silva Gaspar SR, Nunes A, Dias JS, Lopes T: Malignant priapism: penile metastasis originating on a primary prostate adenocarcinoma. Urol Ann. 2015, 7:391-5. 10.4103/0974-7796.152030

15. He D, Zeng J, Li X, et al.: Priapism as the initial manifestation of a penile and lower limb cutaneous metastasis of prostate adenocarcinoma with low serum PSA level. J Androl. 2012, 33:1160-4. 10.2164/jandrol.112.016873

16. Savion M, Livne PM, Mor C, Servadio C: Mixed carcinoma of the prostate with penile metastases and priapism. Eur Urol. 1987, 13:351-2. 10.1159/000472818

17. Barrett-Campbell O, Petkovska I, Slovin SF: Malignant priapism in metastatic prostate cancer: a late event occurring early. Urol Case Rep. 2018, 19:1-3. 10.1016/j.eucr.2018.03.001

18. Matthewman PJ, Oliver RT, Woodhouse CR, Tiptaft RC: The role of chemotherapy in the treatment of penile metastases from carcinoma of the bladder. Eur Urol. 1987, 13:310-2. 10.1159/000472807

19. Kvarstein B: Bladder cancer complicated with priapism. A case report . Scand J Urol Nephrol Suppl. 1996, 179:155-6.

20. Sonmez NC, Coskun B, Arisan S, Guney S, Dalkilic A: Early penile metastasis from primary bladder cancer as the first systemic manifestation: a case report. Cases J. 2009, 2:7281.

21. Spinapolice EG, Fuccio C, Rubino B, et al.: Penile metastases from bladder and prostate cancer detected by PET/CT: a report of 3 cases and a review of literature. Clin Genitourin Cancer. 2014, 12:e155-9. 10.1016/j.clgc.2014.03.013

22. Ellanti P, Connolly SS, McDermott R, Crotty PL, Grainger R: Malignant priapism: a case report . Ir J Med Sci. 2011, 180:921-2. 10.1007/s11845-010-0608-X

23. Al-Mufarrej F, Kamel MH, Mohan P, Hickey D: Tricorporal priapism postradical cystoprostatectomy: first sign of recurrent urogenital malignancy. Int J Urol. 2006, 13:460-2. 10.1111/j.1442-2042.2006.01333.x

24. Zhu YP, Yao XD, Zhang HL, Shen YJ, Huang D, Ye DW: Penile metastasis from primary bladder cancer: a study of 8 cases and review of the literature. Onkologie. 2012, 35:196-9. 10.1159/000337405

25. Ahmed H, Elsamra S, Sigman M: Case of malignant priapism and review of the literature . Med Health R I. 2012, 95:14-5.

26. Daniels GF, Jr., Schaeffer AJ: Renal cell carcinoma involving penis and testis: unusual initial presentations of metastatic disease. Urology. 1991, 37:369-73. 10.1016/0090-4295(91)80269-d

27. Puppo P, Perachino M, Ricciotti G, Vitali A: Malignant priapism due to a huge renal carcinoma . Eur Urol. 1992, 21:169-71. 10.1159/000474828

28. Nezu FM, Dhir R, Logan TF, Lavelle J, Becich MJ, Chancellor MB: Malignant priapism as the initial clinical manifestation of metastatic renal cell carcinoma with invasion of both corpora cavernosum and spongiosum. Int J Impot Res. 1998, 10:101. 10.1038/sj.ijir.3900342

29. Zhu J, Xue B, Yang D, Zang Y, Shan Y: Malignant priapism due to renal cancer: a case report of first manifestation of systemic spread. Iran Red Crescent Med J. 2014, 16:e9507.

30. Liu S, Zeng F, Qi L, et al.: Malignant priapism secondary to isolated penile metastasis from a renal pelvic carcinoma. Can Urol Assoc J. 2014, 8:E558-60. 10.5489/cuaj.1695

31. Valadez RA, Wheeler JS, Canning JR Jr, Moylan DJ: Metastatic transitional cell carcinoma to penis. Urology. 1987, 29:394-7. 10.1016/0090-4295(87)90503-6

32. Nunes B, Matias M, Alves A, Jorge M: Metastasis to the glans penis: an unusual site of rectal cancer recurrence. Acta Med Port. 2015, 28:525-7. 10.20344/amp.5775

33. Park JC, Lee WH, Kang MK, Park SY: Priapism secondary to penile metastasis of rectal cancer. World J Gastroenterol. 2009, 15:4209-11. 10.3748/wjg.15.4209

34. Persec Z, Persec J, Sovic T, Rako D, Savic I, Marinic DK: Penile metastases of rectal adenocarcinoma . J Visc Surg. 2014, 151:53-5. 10.1016/j.jviscsurg.2013.08.009

35. Kapoor R, Bera A, Saikia UN, Kumar R, Khosla D, Kumar N: Penile metastasis from carcinoma of caecumunusual cause of priapism: a case report and review of literature. Indian J Surg Oncol. 2012, 3:299-301. 10.1007/s13193-012-0180-0

36. Sasikumar A, Harisankar CN, Bhattacharya A, Kapoor R, Mittal BR: 18F-FDG PET/CT in a case of malignant priapism secondary to metastasis from mucoid adenocarcinoma of the cecum. Clin Nucl Med. 2013, 38:e912. 10.1097/RLU.0b013e31824c7604

37. Song L, Wang Y, Weng G: Metastasis in penile corpus cavernosum from esophageal squamous carcinoma after curative resection: a case report. BMC Cancer. 2019, 19:162. 10.1186/s12885-019-5356-3

38. Belville WD, Cohen JA: Secondary penile malignancies: the spectrum of presentation. J Surg Oncol. 1992, 51:134-7. 10.1002/jso.2930510214 


\section{Cureus}

39. Yokoi K, Miyazawa N, Muraki J, Nakazono M, Imura G, Shimamura K: Penile metastasis from lung cancer . Jpn J Clin Oncol. 1992, 22:297-9.

40. Fujimoto N, Hiraki A, Ueoka H, Harada M: Metastasis to the penis in a patient with squamous cell carcinoma of the lung with a review of reported cases. Lung Cancer. 2001, 34:149-52. 10.1016/s01695002(01)00226-4

41. Guo LC, Li G, Wang XM, Zhang M, Huang JA, Chen YB: Penile metastases from primary lung cancer. Case report and literature review. Medicine (Baltimore). 2017, 96:e7307. 10.1097/MD.0000000000007307

42. Cardoso Guimaraes G, De Souza RR, Gadelha Guimaraes AP, et al.: Penile metastasis of chondrosarcoma of the jaw. Urology. 2003, 61:837. 10.1016/s0090-4295(02)02431-7

43. Mondaini N, Mondaini A, Mondaini L, Livi L, Giubilei G, Ponchietti R: Priapism due to sacrococcygeal chordoma metastasis treated with radiation therapy. Int J Impot Res. 2005, 17:300-1. 10.1038/sj.ijir.3901291

44. Sagar SM, Retsas S: Metastasis to the penis from malignant melanoma: case report and review of the literature. Clin Oncol (R Coll Radiol). 1992, 4:130-1. 10.1016/s0936-6555(05)80985-9

45. Gong Z, Zhang Y, Chu H, Lian P, Zhang L, Sun P, Chen J: Priapism as the initial symptom of primary penile lymphoma: a case report. Oncol Lett. 2014, 8:1929-32. 10.3892/ol.2014.2488

46. Sartor O, de Bono JS: Metastatic prostate cancer. N Engl J Med. 2018, 378:645-57. 10.1056/NEJMra1701695 